\title{
INVESTASI DALAM PERSPEKTIF MAQASHID AL-SYARIAH
}

\author{
Suad Fikriawan \\ Mahasiswa Program Doktor Ekonomi Islam \\ Universitas Islam Negeri Sunan Kalijaga Yogyakarta \\ email: suad.fikriawan@gmail.com
}

\begin{abstract}
This study aims to unravel the understanding of Investment law in Islam, especially conventional investment. So far, the Islamic investment model in Indonesia is still ranked under conventional investment in terms of both quality and quantity of capital and market. Thus, if a conventional investment is contaminated by Islamic law as a forbidden investment then its future impact will cloud the conventional investment market image. Thus the maqashid syariah approach needs to be used to re-examine how investment law in Islam. The results of the study in this study state that investments that promise big profits with light business are considered as a common investment and may be done because it is common in the community. However, when viewed from the side of goodness financially very disturbing financial stability both for investors and investors for the condition of the stability of the value of a currency (volatility). Although the investment business was initially based on real and lawful if they sold based on the method of sale in the derivative market will be full of usury, speculation, and vagueness that in some syariah prohibition is prohibited because it does not make good in investing as taught by Islam.
\end{abstract}

Keywords: Investment, Conventional Investment and Maqashid al-Syariah.

\begin{abstract}
Abstrak
Studi ini bertujuan untuk mengurai kembali pemahaman tentang hukum Investasi dalam Islam, terutama investasi konvensional. Selama ini model investasi Islam di Indonesia masih menduduki peringkat di bawah investasi konvesional baik dalam hal kualitas maupun kuantitas permodalan dan pasar. Sehingga bila investasi konvesional diistinbatkan oleh hukum Islam sebagai investasi yang haram maka dampaknya kedepan akan memperkeruh citra pasar investasi konvensional. Maka pendekatan maqashid syariah perlu digunakan untuk mengkaji kembali bagaimana hukum investasi dalam Islam. Hasil studi dalam penelitian ini menyatakan bahwa investasi yang menjanjikan keuntungan besar dengan usaha yang ringan dianggap sebagai investasi yang lumrah dan boleh dilakukan karena sudah umum berlaku di masyarakat. Namun bila ditinjau dari sisi kebaikannya secara finansial sangat mengganggu stabilitas keuangan baik bagi pelaku investor maupun bagi kondisi stabilitas nilai mata uang (volatilitas). Meskipun usaha investasi itu awalnya berbasis riil dan halal tetapi bila kemudian dijual berdasarkan metode penjualan di pasar derivative akan menjadi sarat riba, spekulasi, dan ketidakjelasan yang dalam beberapa dalil syariah dilarang karena tidak menjadikan kebaikan dalam berinvestasi sesuai yang diajarkan oleh Islam.
\end{abstract}

Kata Kunci: Investais, Investasi Konvensional, dan Maqashid al-Syariah. 


\section{PENDAHULUAN}

Setiap manusia memerlukan harta untuk mencukupi segala kebutuhan hidupnya. Karenanya, manusia akan selalu berusaha memperoleh harta kekayaan tersebut. Salah satunya melalui kegiatan investasi. Kata investasi merupakan kata adopsi dari bahasa Inggris, yaitu investment. Kata invest sebagai kata dasar dari investment memiliki arti menanam. Secara sederhana, investasi dapat diartikan sebagai suatu kegiatan menanam harta yang bertujuan untuk mengembangkannya. Secara lebih praktis, investasi merupakan suatu komitmen atas sejumlah dana atau sumber daya lainnya yang dilakukan pada saat sekarang dengan harapan memperoleh sejumlah keuntungan di masa yang akan datang. ${ }^{1}$ Sedangkan dalam bahasa arab istismar yang secara etimologi berarti menjadi berbuah (berkembang). Istismar secara terminologi berarti menjadikan harta berubah (berkembang) dan bertambah jumlahnya. Investasi merupakan bagian penting dalam perekonomian. Investasi adalah kegiatan usaha yang mengandung risiko karena berhadapan dengan unsur ketidakpastian. Dengan demikian perolehan kembaliannya (return) tidak pasti dan tidak tetap. ${ }^{2}$

Pada umunya investasi dibedakan menjadi dua, yaitu investasi pada financial asset dan investasi pada real asset. Investasi financial asset dilakukan dipasar uang, misalnya berupa sertifikat deposito, commercial paper, Surat Berharga Pasar Uang (SBPU), dan lain sebagainya. Investasi pada real asset dapat dilakukan dengan pembelian aset produktif, pendirian pabrik, pembukaan pertambangan, perkebunan, dan sebagainya. Investasi dalam tulisan ini dimaksudkan sebagai financial assets. Berbagai macam kegiatan investasi tersebut di atas pada umumnya memiliki tujuan yang sama, profitabilitas

\footnotetext{
${ }^{1}$ Indah Yuliana, Investasi Produk Keuangan Syariah (Malang: UIN Maliki Press, 2010), 1. Syariah, 2.
}

atau penghasilan (return). Tujuan akhir yang diharapkan, seorang investor harus mengambil keputusan yang tepat untuk memilih objek serta mempertimbangkan waktu dan kondisi. ${ }^{3}$

Pada umumnya hubungan antara risiko (risk) dan tingkat pengembalian yangdiharapkan (expected rate of return) bersifat linier. Artinya, semakin tinggi tingkat risiko, maka semakin tinggi pula tingkat pengembalian yang diharapkan. Setelah menetapkan tujuan, langkah selanjutnya melakukan analisis terhadap suatu efek atau beberapa efek. Salah satu tujuan dari penilaian ini adalah untuk melakukan identifikasi harga suatu efek. Penilaian keberhasilan investasi tidak saja ditentukan oleh tingkat pengembalian yang tinggi sebagaimana terkonsep dalam ekonomi konvensional. ${ }^{4}$

Dewasa ini kecenderungan motivasi berinvestasi mulai mengalami pergeseran, dimana investasi tidak saja dipandang sebagai kegiatan yang memberikan kepuasan finansial atau tingkat pengembalian yang tinggi, namun juga kepuasan spiritual. Kecenderungan investasi semacam ini disebut sebagai ethical investment, yakni investasi yang dapat dipertanggungjawabkan secara sosial, karena menggunakan pertimbangan etika (ethical screening). Unsur spekulasi dalam perilaku investasi konvensional diyakini oleh banyak kalangan memberikan kontribusi bagi berbagai krisis perekonomian dunia. Sebagai contoh, great depression pada tahun 1930-an diawali dengan spekulasi besar-besaran di Wall Street. Selain itu, devaluasi poundsterling pada tahun 1967dan krisis mata uang Frank pada tahun 1969, dan terakhir devaluasi Bath Thailand menyebabkan penarikan investasi besar-besaran di pasar modal yang

${ }^{3}$ Henry Faizal Noor, Investasi, Pengelolaan Keuangan Bisnis dan Pengembangan Ekonomi Masyarakat (Jakarta: PT. Indeks, 2009), 24.

${ }^{4}$ Henry Faisal Noor, Investasi, Pengelolaan Keuangan Bisnis dan Pengembangan Ekonomi Masyarakat, 27. 
kemudian menimbulkan krisis ekonomi. Hal-hal tersebut, menurut Esta, membawa kesadaran bagi investor akan pentingnya investasi yang lebih etis. ${ }^{5}$

Secara normatif, ada beberapa landasan etika dalam Islam: pertama, landasan Tauhid. Landasan ini merupakan landasan filosofis yang dijadikan sebagai fondasi bagi setiap umat muslim dalam melakukan tindakanya. implementasinya dalam konteks ekonomi Islam bahwa segala aktivitas ekonomi yang berlandaskan pada aqidah ketauhidan dipercaya berasal dari Allah dan bertujuan akhir untuk Allah. Manusia tidak memiliki kedudukan yang mutlak terhadap pemanfaatan dan pendistribusian sumber-sumber ekonomi dengan sekehendak hatinya. ${ }^{6}$

Kedua, landasan Keadilan dan kesejajaran. Adil salah satu dari nilai-nilai ekonomi yang ditetapkan dalam Islam, merupakan landasan yang berkaitan langsung dengan pembagian manfaat kepada semua komponen dan pihak yang terlibat dalam usaha ekonomi. Landasan kesejajaran berkaitan dengan kewajiban terjadinya sirkulasi kekayaan pada semua anggota masyarakat dan mencegah terjadinya konsentrasi ekonomi hanya pada segelintir orang. Islam membolehkan adanya kepemilikan kekayaan oleh individu (private property), meskipun demikian Islam menetukan pula bagaimana cara yang baik untuk memilikinya. Sebagai cita-cita sosial, prinsip keadilan dan kesejajaran merupakan penjabaran yang lengkap atas seluruh kebijakan dasar dalam institusi sosial ekonomi. $^{7}$

Kslam metiga, landasan kehendak bebas. sunatullah terlahir dengan memiliki kehendak bebas, yakni potensi menetukan

${ }^{5}$ Nurul Huda dan Mustafa Edwin Nasution, Investasi pada Pasar Modal Syari'ah (Jakarta: Kencana, 2007), 15.

${ }^{6}$ Nurul Huda dan Mustafa Edwin Nasution, Investasi pada Pasar Modal Syari'ah, 15.

${ }^{7}$ Nurul Huda dan Mustafa Edwin Nasution, Investasi pada Pasar Modal Syari'ah, 15. pilihan yang beragam, oleh karenanya kebebasan manusia tidak dibatasi, maka manusia memiliki kebebasan pula untuk menetukan pilihan yang salah atau pun yang benar. Manusia diberikan kebebasan oleh Allah SWT untuk memilih satu dari dua pilihan, yaitu dengan menaati ketentuan Allah untuk membuat pilihan yang benar ataukah melawan ketentuan Allah dengan membuat pilihan yang salah. Dalam konsep Islam, kebebasan individu sifatnya sangat relative karena kebebasan mutlak adalah hak dan milik Allah. ${ }^{8}$

Berdasarkan tiga prinsip di atas, maka muncullah konsep Investasi dalam Islam. Menurut Huda dan Nasution, investasi merupakan salah satu ajaran dari konsep Islam yang memenuhi proses tadrij (gradasi) dan trichotomy pengetahuan (pengetahuan instrumen, pengetahuan intelektual dan pengetahuan spiritual). Hal tersebut dapat dibuktikan bahwa konsep investasi selain sebagai pengetahuan juga bernuansa spiritual karena menggunakan norma syariah, sekaligus merupakan hakikat dari sebuah ilmu dan amal, oleh karenanya investasi sangat dianjurkan bagi setiap muslim. ${ }^{9}$ Hal tersebut dijelaskan dalam alQur'an surat al-Hasyr ayat 18 berikut:

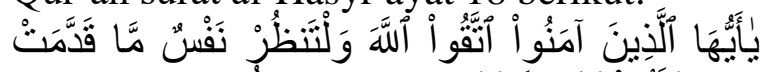

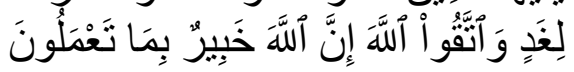

Artinya: "Hai orang-orang yang beriman, bertakwalah kepada Allah dan hendaklah setiap diri memperhatikan apa yang telah diperbuatnya untuk hari esok (akhirat); dan bertakwalah kepada Allah, sesungguhnya Allah Maha Mengetahui apa yang kamu kerjakan". 10

Adapun praktik Investasi Syariah di Indonesia dimulai sejak dibukanya Pasar Modal Syariah pada tanggal 14 Maret 2003

\footnotetext{
${ }^{8}$ Nurul Huda dan Mustafa Edwin Nasution, Investasi pada Pasar Modal Syari'ah, 15.

${ }^{9}$ Nurul Huda dan Mustafa Edwin Nasution, Investasi pada Pasar Modal Syari'ah, 16.

${ }^{10} \mathrm{QS}$. Al-Hasyr (59): 18.
} 
antara Bapepam LK dengan Dewan Syariah Nasional MUI melalui hubungan koordinasi, konsultasi, dan kerjasama untuk pengaturan yang efektif dan efisien dalam bentuk penyusunan peraturan Bapepam LK dan Fatwa DSN MUI, penelaahan pendaftaran penerbitan efek syariah, pengawasan kepatuhan pemenuhan prinsip syariah dan pengembangan produk investasi serta peningkatan kualitas SDM Pasar Modal Syariah. $^{11}$ Meskipun hingga kini perkembangan Pasar Modal Syariah telah cukup pesat dengan berbagai varian produknya serta fatwa-fatwa yang mengiringinya telah disahkan DSN-MUI, namun dalam konteks ini penulis akan mereview kembali bagaimana praktik investasi syariah pada Pasar Modal Syariah ditinjau dari perspektif Maqashid alSyariah, yang secara spesifik penulis memfokuskan pada jenis produk investasi saham syariah, obligasi syariah (sukuk) dan Reksadana Syariah yang diperjualbelikan dalam pasar primer maupun di pasar sekunder.

\section{LITERATURE REVIEW}

Studi tentang pemikiran maqasid syariah dalam berbagai aspek persoalan kehidupan terutama bidang ekonomi dan diskursus tentang investasi banyak sekali menyoroti landasan hukum, mekanisme produk dan sebagainya. Diantara penelitian terdahulu, yaitu pertama, Mohamad Sabri Haron, ${ }^{12}$ dalam maqasid syariah tentang harta menjadi wasilah yang penting untuk mencapai objektif yang paling tinggi yaitu perlindungan terhadap agama (Hifdzu adDin). Untuk merealisasikan hal ini, Malaysia telah meletakkan ekonomi sebagai suatu jihad penting untuk mencapai kesejahteraan dalam kehidupan. Malaysia

\footnotetext{
${ }^{11}$ Andrian Sutedi, Pasar Modal Syariah (Yogyakarta: Sinar Grafika, 2005), 4.

${ }^{12}$ Mohamad Sabri Haron, "Wealth Protection in The Context of Maqasid Syariah: Malaysia's Role ini Realizing The Concept of Economic Jihad", Jurnal Hadhari Edisi Khas, Vol. 2, No. 2 (Desember 2017): 144.
}

telah memperkenalkan Akta Bank Islam 1983 yang mewujudkan Bank Islam Malaysia Berhad. Dalam masa yang sama sistem perbankan konvensional juga mewujudkan tingkat persaingan dengan sistem perbankan Islam yang kini perkembangannya semakin meluas di bawah Bank Negara Malaysia. Paper ini menjelaskan konsep perlindungan terhadap harta menurut Islam dalam konteks maqasid syariah dan bagaimana peranan Malaysia untuk mengaplikasinya khususnya kepada masyarakat Islam dilanjutkan institusiinstitusi keuangan Islam yang berpotensi di Malaysia menerusi pendekatan jihad ekonomi.

Kedua, Zariatul Khisan, ${ }^{13}$ Kinerja perbankan syariah tidak hanya terdiri dari aspek kinerja keuangan saja, tetapi juga dilihat dari aspek maqasid syariah. Pengukuran kinerja bank syariah dari aspek syariah merupakan hal yang sangat penting diperlukan dalam mengukur kinerja perbankan syariah. Pelaksanaan maqasid syariah merupakan sebuah kewajiban bagi setiap individu atau suatu lembaga keuangan Islam seperti bank syariah, namun sampai pada saat ini belum ada pengukuran kinerja dan laporan maqasid syariah yang dilakukan terhadap bank syariah. Dari hasil penelitian menunjukkan bahwa pengukuran kinerja perbankan syariah dapat ditinjau dari profitabilitas dan maqasid syariah. Pengukuran kinerja maqasid syariah dapat dilakukan dengan pendekatan model IMS. Hasil penelitian ini juga menunjukkan kinerja setiap bank syariah dalam suatu diagram perbandingan sebagai hasil dari perbandingan kinerja profitabilitasnya dengan pelaksanaan maqasid syariah yang telah dilaksankan atau dilakukan oleh bank syariah.

Berdasarkan kedua penelitian terdahulu di atas, hanya berpusat maqasid

\footnotetext{
${ }^{13}$ Zariatul Khisan, “Analisis kinerja perbankan syariah ditinjau dari profitabilitas dan maqasid syariah tahun 2010-2013)". Tesis (Malang: Universitas Islam Negeri Malik Ibrahim, 2015), 24.
} 
dan gambaran penjelasan permasalahan yang ada. Penelitian ini menjadi penting untuk membahas pandangan dan tujuantujuan maqasid syariah terhadap investasi di Indonesia.

\section{METODOLOGI PENELITIAN}

Jenis penelitian yang digunakan adalah penelitian kepustakaan, merupakan penelitian yang penemuanya didapatkan dengan mencari data dari berbagai literatur dan referensi yang berhubungan dengan materi pembahasan. ${ }^{14}$ Oleh karena itu, penelitian tentang Investasi dalam Prespektif Maqasid al-Syariah dalam penelitian ini menggunakan metode review dokumen dan trend analysis.

Pendekatan penelitian yang dilakukan menggunakan pendekatan kualitatif normatif, yaitu sebagaimana cara yang digunakan dalam penelitian hukum yang dilakukan dengan cara meneliti bahan pustaka yang ada. ${ }^{15}$

Teknik pengumpulan data merupakan langkah yang paling strategis dalam penelitian, karena tujuan utama dari penelitian adalah mendapatkan data. ${ }^{16}$ Peneliti melakukan teknik pengumpulan data dengan melakukan penelitian terhadap berbagai literatur yang dilakukan untuk mencari konsep yang ada relevansinya dengan topik pembahasan melalui pengkajian buku-buku, jurnal, majalah, serta pendapat para ahli secara tidak langsung, yang kemudian akan dianalisis secara mendalam. Selain itu, penelitian ini menggunakan teknis analisis deskriptif, yaitu analisis dengan cara memaparkan data

\footnotetext{
${ }^{14}$ Moh. Nazir, Metode Penelitian (Bandung: Ghalia Indonesia, 2003), 193.

${ }^{15}$ Soerjono Soekanto dan Sri Mamudji, Penelitian Hukum Normatif Suatu Tinjauan Singkat, Cet. 11 (Jakarta: PT. Raja Grafindo Persada, 2009), 13-14.

${ }^{16}$ Sugiyono, Metode Penelitian Kuantitatif Kualitatif Dan R \& D (Bandung: Alfabeta, 2013), 224.
}

yang telah terkumpul dan tersusun secara sistematis. ${ }^{17}$

Sumber diperoleh dari dokumen dan informasi beberapa temuan-temuan di berbagai jurnal dan hasil penelitian sebelumnya. Dokumen tersebut telah melalui tahapan-tahapan analisis dari berbagai keabsahan data atau sumber yang banyak dikaji oleh para peneliti, serta dianalisis dengan fakta bersifat obyektif melihat Investasi dalam Prespektif Maqasid al-Syariah yang berkembang di Indonesia.

\section{KONSEP DASAR}

\section{Pengertian Investasi}

Investasi adalah pengaitan sumber-sumber dalam jangka panjang untuk menghasilkan laba di masa yang akan datang. ${ }^{18}$ Investasi juga dapat didefinisikan sebagai penanaman modal atau pemilikan sumber-sumber dalam jangka panjang yang akan bermanfaat pada beberapa periode akuntansi yang akan datang. ${ }^{19}$ Investasi dapat pula didefinisikan sebagai penempatan sejumlah dana pada saat ini dengan harapan untuk memperoleh keuntungan di masa mendatang. Umumnya investasi dapat dibedakan menjadi dua, ${ }^{20}$ yaitu:

1. Investasi pada financial assets. Investasi pada financial assets dapat dibedakan lagi menjadi dua, yaitu:

a. Investasi pada financial assets yang dilakukan di pasar uang, misalnya berupa sertifikat deposito, commercial paper, surat berharga pasar uang dan lainnya.

b. Investasi pada financial assets yang dilakukan di pasar modal, misalnya berupa saham, obligasi, waran, opsi dan lainnya.

\footnotetext{
${ }^{17}$ Jalaludin Rahmat, Metodologi Hukum (Jakarta: Fajar Agung, 1997), 134.

${ }^{18}$ Mulyadi, Sistem Akuntansi Manajemen, Edisi Ketiga (Jakarta: Salemba Empat, 2001), 284.

${ }^{19}$ Supriyono, Akuntansi Biaya (Jakarta: BPFE, 1987), 424.

${ }^{20}$ Abdul Halim, Analisis Investasi (Jakarta: Salemba Empat, 2003), 2.
} 
2. Investasi pada real asset. Investasi pada real asset diwujudkan dalam bentuk pembelian asset produktif, pendirian pabrik, pembukaan pertambangan, pembukaan perkebunan dan lainnya. Investasi pada real asset termasuk dalam capital budgeting, yaitu keseluruhan proses perencanaan dan pengambilan keputusan tentang pengeluaran dana, di mana jangka waktu kembalinya dana tersebut lebih dari setahun. Dengan demikian capital budgeting mempunyai arti yang sangat penting bagi perusahaan, ${ }^{21}$ karena:

a. Dana yang dikeluarkan akan terikat untuk jangka waktu yang panjang. Ini berarti bahwa perusahaan harus menunggu selama waktu yang panjang atau lama sampai keseluruhan dana yang tertanam dapat diperoleh kembali oleh perusahaan.

b. Investasi dalam aktiva tetap menyangkut harapan terhadap hasil penjualan di waktu yang akan datang. Kesalahan dalam mengadakan forecasting akan dapat mengakibatkan adanya over investment atau under investment dalam aktiva tetap. Apabila over investment akan memberikan beban tetap yang besar bagi perusahaan. Sebaliknya jika under investment akan mengakibatkan kekurangan peralatan, yang ini dapat mengakibatkan perusahaan bekerja dengan harga pokok yang tinggi sehingga mengurangi daya bersaingnya atau kemungkinan lain ialah kehilangan sebagian dari pasar bagi produknya.

c. Pengeluaran dana untuk keperluan tersebut biasanya meliputi jumlah

\footnotetext{
${ }^{21}$ Bambang Riyanto, Dasar-dasar Pembelanjaan (Yogyakarta: BPFE, 1995), 121.
}

yang besar. Jumlah dana yang besar itu mungkin tidak dapat diperoleh dalam jangka waktu yang pendek atau mungkin tidak dapat diperoleh sekaligus.

d. Kesalahan dalam pengambilan keputusan mengenai pengeluaran modal tersebut akan mempunyai akibat yang panjang dan berat. Kesalahan dalam pengambilan keputusan ini tidak dapat diperbaiki tanpa adanya kerugian.

Adapun tempat penjualan surat berharga yang berbasis pada financial asset umumnya terjadi di pasar perdana (primary market) dan pasar sekunder (secondary market). ${ }^{22}$

1. Pasar Primer. Pasar primer adalah penawaran saham pertama kali dari emiten kepada para pemodal selama waktu yang ditetapkan oleh pihak penerbit (issuer) sebelum saham tersebut belum diperdagangkan di pasar sekunder. Biasanya dalam jangka waktu sekurang-kurangnya enam hari kerja. Harga saham di pasar perdana ditetukan oleh penjamin emisi dan perusahaan yang go public berdasarkan analisis fundamental perusahaan yang bersangkutan. Dalam pasar perdana, perusahaan akan memperoleh dana yang diperlukan. Perusahaan dapat menggunakan dana hasil emisi untuk mengembangkan dan memperluas barang modal untuk memproduksi barang dan jasa. Selain itu dapat juga digunakan untuk melunasi hutang dan memperbaiki struktur pemodalan usaha. Harga saham pasar perdana tetap, pihak yang berwenang adalah penjamin emisi dan pialang, tidak dikenakan komisi dengan pemesanan yang dilakukan melalui agen penjualan.

\footnotetext{
${ }^{22}$ Abdul Halim, Analisis......3.
} 
2. Pasar Sekunder. Pasar sekunder adalah tempat terjadinya transaksi jual-beli saham diantara investor setelah melewati masa penawaran saham di pasar perdana, dalam waktu selambatlambatnya 90 hari setelah ijin emisi diberikan maka efek tersebut harus dicatatkan di bursa. Dengan adanya pasar sekunder para investor dapat membeli dan menjual efek setiap saat. Sedangkan manfaat bagi perusahaan, pasar sekunder berguna sebagai tempat untuk menghimpun investor lembaga dan perseorangan. Harga saham pasar sekunder berfluktuasi sesuai dengan ekspetasi pasar, pihak yang berwenang adalah pialang, adanya beban komisi untuk penjualan dan pembelian, pemesanannya dilakukan melalui anggota bursa, jangka waktunya tidak terbatas. Tempat terjadinya pasar sekunder di dua tempat, yaitu:

a. Bursa regular. Bursa reguler adalah bursa efek resmi seperti Bursa Efek Indonesia (BEI).

b. Bursa paralel. Bursa paralel atau over the counter adalah suatu sistem perdagangan efek yang terorganisir di luar bursa efek resmi, dengan bentuk pasar sekunder yang diatur dan diselenggarakan oleh Perserikatan Perdagangan Uang dan Efek-efek (PPUE), diawasi dan dibina oleh BAPEPAM. Over the counter karena pertemuan antara penjual dan pembeli tidak dilakukan di suatu tempat tertentu tetapi tersebar diantara kantor para broker atau dealer.

\section{Investasi dalam Pandangan Islam}

Bila mengacu pada tulisan Sumiyanto dalam Institute of Sharia Economic Studies: Islam sangat mendorong dan menganjurkan mengembangkan harta melalui kegiatan investasi. Sebaliknya, Islam melarang mendiamkan harta, berspekulasi terhadap harta, termasuk modal sehingga tidak produktif. Islam melarang menimbun harta dan menumpuk harta kekayaan, sebagaimana keterangan dalam al-Qur'an:

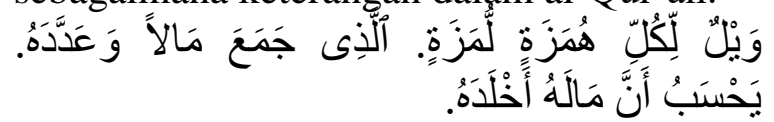

Artinya: "Kecelakaanlah bagi setiap pengumpat lagi pencela.Yang mengumpulkan harta dan menghitung-hitung. Dia mengira bahwa hartanya itu dapat mengkekalkannya". 23

Tindakan seperti itu menyia-nyiakan karunia Allah dari fungsi yang sebenarnya dan secara ekonomi membahayakan karena menghambat pertumbuhan modal. Terhambatnya pertumbuhan modal akan menurunkan jumlah modal kerja yang tersedia untuk investasi. Hal ini juga berarti menghambat pembangunan ekonomi di suatu Negara. Adanya pelarangan penumpukan dan menimbunan kekayaan itu, mengharuskan agar kekayaan tersebut diputar. Dalam al-Qur'an disebutkan:

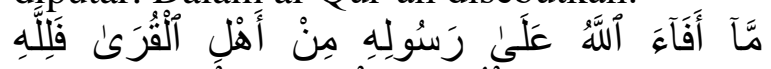

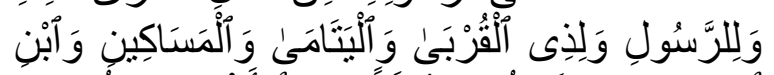

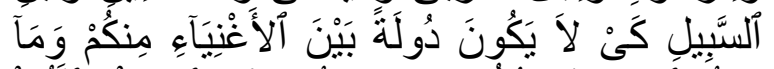

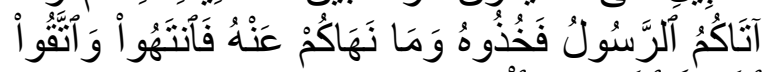

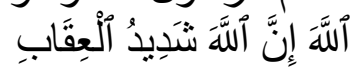

Artinya: "Apa saja harta rampasan (fai-i) yang diberikan Allah kepada RasulNya (dari harta benda) yang berasal dari penduduk kota-kota maka adalah untuk Allah, untuk Rasul, kaum kerabat, anak-anak yatim, orang-orang miskin dan orangorang yang dalam perjalanan, supaya harta itu jangan beredar di antara orang-orang kaya saja di antara kamu. Apa yang diberikan Rasul kepadamu, maka terimalah. Dan apa yang dilarangnya bagimu,

\footnotetext{
${ }^{23}$ QS. Al-Humazah (104): 1-3.
} 
maka tinggalkanlah. Dan bertakwalah kepada Allah. Sesungguhnya Allah amat keras hukumannya". ${ }^{24}$ bahwa:

Surat An-Nisa' ayat 9, dijelaskan

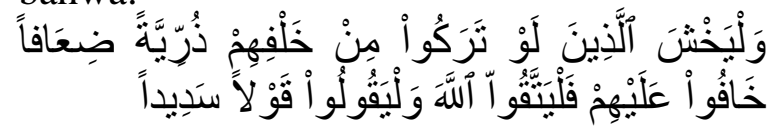

Artinya: "Dan hendaklah takut kepada Allah orang-orang yang seandainya meninggalkan dibelakang mereka anak-anak yang lemah, yang mereka khawatir terhadap (kesejahteraan) mereka. Oleh sebab itu hendaklah mereka bertakwa kepada Allah dan hendaklah mereka mengucapkan perkataan yang benar". ${ }^{25}$

Kemudian dalam surat Al-Baqarah 261, dijelaskan:

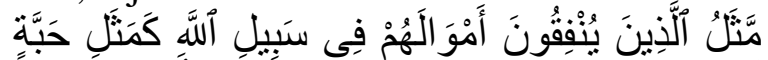

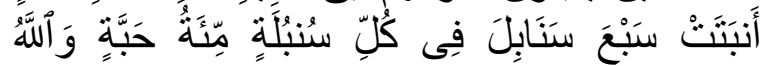

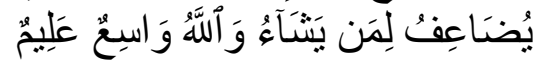

Artinya: "Perumpamaan (nafkah yang dikeluarkan oleh) orang-orang yang menafkahkan hartanya di jalan Allah adalah serupa dengan sebutir benih yang menumbuhkan tujuh bulir, pada tiap-tiap bulir seratus biji. Allah melipat gandakan (ganjaran) bagi siapa yang Dia kehendaki. Dan Allah Maha Luas (karunia-Nya) lagi Maha Mengetahui", ${ }^{26}$

Dalam surat Yusuf ayat 43-44 dijelaskan bahwa:

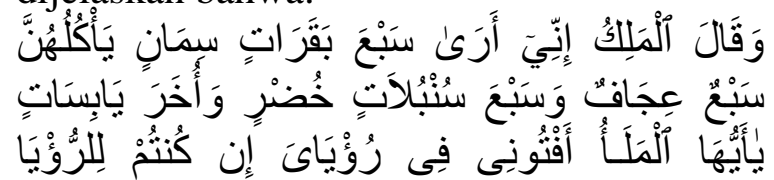

${ }^{24} \mathrm{QS}$. Al.Hasyr (59): 7.

${ }^{25}$ QS. An-Nisa' (4): 9.

${ }^{26}$ QS. Al-Baqarah (2): 261.

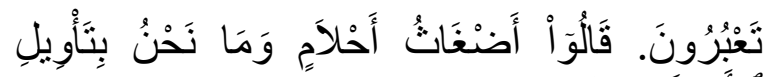

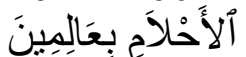

Artinya: "Raja berkata (kepada orangorang terkemuka dari kaumnya): "Sesungguhnya aku bermimpi melihat tujuh ekor sapi betina yang gemuk-gemuk dimakan oleh tujuh ekor sapi betina yang kuruskurus dan tujuh bulir (gandum) yang hijau dan tujuh bulir lainnya yang kering". Hai orang-orang yang terkemuka: "Terangkanlah kepadaku tentang ta'bir mimpiku itu jika kamu dapat mena'birkan mimpi”. Mereka menjawab: "(Itu) adalah mimpi-mimpi yang kosong dan kami sekali-kali tidak tahu menta'birkan mimpi itu". 27

Menurut Charpa $^{28}$ kewajiban mengelola harta dan modal menjadi lebih kuat bila umat Islam menyadari bahwa Nabi Muhammad SAW sendiri melakukan upayaupaya produktif dan investasi dengan sabdanya : "Jika seorang Muslim menanam pohon atau menghidupkan ladang dan ada burung atau orang atau binatang memakan dari padanya, hal ini akan dihitung sebagai amal sedekah baginya". Kemudian Khalifah Umar bin Khaththab juga pernah berkata, "Siapa saja yang mempunyai kekayaan hendaknya mengembangkannya dan siapa saja yang mempunyai tanah, hendaknya menanaminya". Dari beberapa landasan hukum tersebut nampak jelas bahwa investasi atau kegiatan produktif lainnya sangatlah dianjurkan dalam Islam demi tercapainya tujuan syari'ah (maqashid AlSyariah) yaitu kebaikan.

Keputusan seorang Muslim untuk melakukan investasi pada suatu bidang usaha tertentu didasarkan atas inisiatif sendiri, bukan karena paksaan, juga mitra

\footnotetext{
${ }^{27}$ QS. Yusuf (12): 43-44.

${ }^{28}$ Umer Chapra, Sistem Moneter Islam (Jakarta: Gema Insani Press, 2000), 65.
} 
kerja bekerja sama atas inisiatifnya sendiri. Dengan demikian, aktivitas investasi tersebut akan jauh dari unsur-unsur paksaan, aniaya dan zalim menzalimi (QS. An-Nisa : 29 dan Al-Baqarah : 279). Secara spesifik, mengutip pendapat Sula, ${ }^{29}$ tujuan Investasi adalah untuk mendapatkan keuntungan di masa yang akan datang. Keuntungan dalam pandangan Islam memiliki aspek yang holistik.

1. Aspek material atau finansial, artinya suatu bentuk investasi hendaknya menghasilkan manfaat finansial yang kompetitif dibandingkan dengan bentuk investasi lainnya.

2. Aspek kehalalan, artinya suatu bentuk investasi harus terhindar dari bidang maupun prosedur yang syubhat dan/atau haram. Suatu bentuk investasi yangtidak halal hanya akan membawa pelakunya kepada kesesatan serta sikap danperilaku yang destruktif secara individu maupun sosial.

3. Aspek sosial dan lingkungan, artinya suatu bentuk investasi hendaknya memberikan kontribusi positif bagi masyarakat banyak dan lingkungan sekitar,baik untuk generasi saat ini maupun yang akan datang.

4. Aspek pengharapan kepada ridha Allah, artinya suatu bentuk investasi tertentu itu dipilih adalah dalam rangka mencapai ridha Allah. Kesadaran adanya kehidupan yang abadi, menjadi panduan bagi ketiga aspek di atas.

Sedangkan menurut Pontjowinoto dalam Huda dan Nasution,30 beberapa prinsip dasar transaksi menurut syariah sebagai berikut :

1. Transaksi dilakukan atas harta yang memberikan nilai manfaat dan

\footnotetext{
${ }^{29}$ M. Syakir Sula, Asuransi Syaraiah: Konsep dan Sistem Operasional (Jakarta: Gema Insani Press, 2004), 25.

${ }^{30}$ Nurul Huda dan Mustofa Edwin Nasution, Pasar Modal Syariah (Jakarta: Kencana, 2007), 2324.
}

menghindari setiap transaksi yang zalim. Setiap transaksi yang memberikan manfaat akan dilakukan bagi hasil.

2. Uang sebagai alat pertukaran bukan komoditas perdagangan, fungsinya sebagai alat pertukaran nilai yang menggambarkan daya belisuatu barang atau harta, sedangkan manfaat atau keuntungan yang ditimbulkannya berdasarkan atas pemakaian barang atau harta yang dibeli dengan uang tersebut.

3. Setiap transaksi harus transparan tidak menimbulkan kerugian atau unsur penipuan di salah satu pihak baik secara sengaja maupun tidak sengaja.

4. Risiko yang mungkin timbul harus dikelola sehingga tidak menimbulkan risiko yang besar atau melebihi kemampuan menanggung risiko.

5. Dalam Islam setiap transaksi yang mengharapkan hasil harus bersedia menanggung risiko.

6. Manajemen yang diterapkan adalah manajemen islami yang tidak mengandung unsur spekulatif dan menghormati hak asasi manusia serta menjaga lestarinya lingkungan hidup.

Produk Investasi Islam: Saham Syariah, Sukuk dan Reksadana syariah Saham Syariah

Saham (Stock) merupakan salah satu instrument pasar keuangan yang paling popular. Saham dapat didefinisikan sebagai tanda penyertaan modal seseorang atau pihak (badan usaha) dalam suatu perusahaan atau perseroan terbatas. Dengan menyertakan modal tersebut maka pihak tersebut memiliki klaim atas pendapatan perusahaan, klaim atas asset perusahaan, dan berhak hadir dalam Rapat Umum Pemegang Saham.

Menurut Undang-Undang Nomor 7 tahun 1992 tentang Perseroan Terbatas, bahwa saham adalah surat berharga yang 
dikeluarkan perusahaan yang berbentuk PT

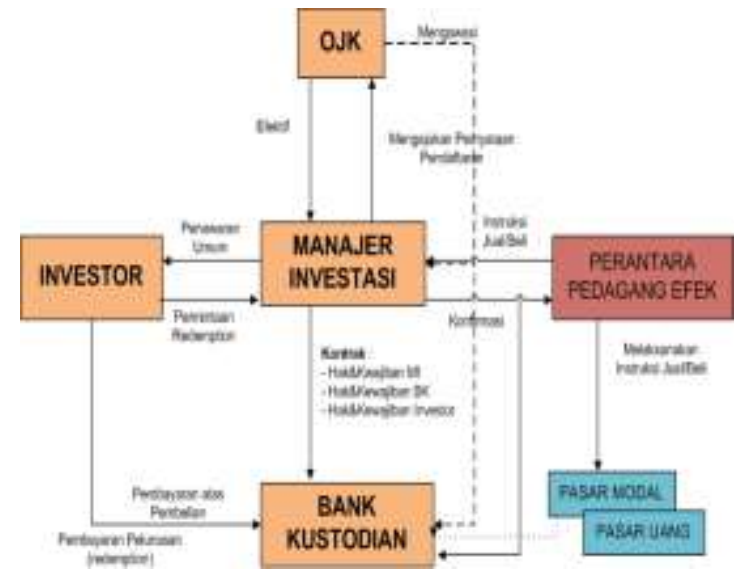

atau yang biasa disebut Emiten. Saham menyatakan bahwa pemilik saham tersebut adalah juga sebagian dari pemilik perusahaan tersebut. Wujud saham berupa selembar kertas (warkat) yang menerangkan siapa pemiliknya. Akan tetapi sekarang ini sistem tanpa warkat sudah dilakukan di Bursa Efek Jakarta dengan bentuk kepemilikan tidak lagi berupa lembaran saham yang diberi nama pemiliknya tetapi sudah berupa account atas nama pemilik atau saham tanpa warkat. Jadi pergeseran transaksi akan semakin cepat dan mudah karena tidak melalui prosedur administratif yang rumit. ${ }^{31}$

Produk investasi berupa saham pada prinsipnya sudah sesuai dengan ajaran Islam. Dalam teori percampuran, Islam mengenal akad syirkah atau musyarakah yaitu suatu kerja sama antara dua atau lebih pihak untuk melakukan usaha dimana masing-masing pihak menyetorkan sejumlah dana, barang, atau jasa. ${ }^{32}$ Dalam beberapa ayat Al-Quran dan hadits Nabi telah diterangkan sebagaimana berikut:

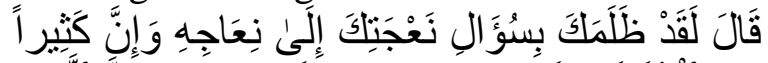

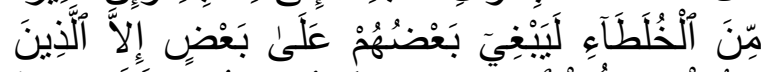

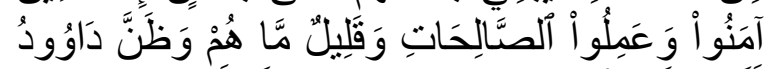

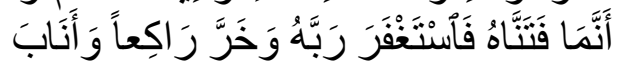

Artinya: "Daud berkata: "Sesungguhnya dia telah berbuat zalim kepadamu

\footnotetext{
${ }^{31}$ Abdul Aziz, Manajemen Investasi Syariah (Bandung: Penerbit Alfabeta, 2010), 83.

${ }^{32}$ Abdul Aziz, Manajemen Investasi Syariah,
} 84. dengan meminta kambingmu itu untuk ditambahkan kepada kambingnya. Dan sesungguhnya kebanyakan dari orang-orang yang berserikat itu sebahagian mereka berbuat zalim kepada sebahagian yang lain, kecuali orang-orang yang beriman dan mengerjakan amal yang saleh; dan amat sedikitlah mereka ini". Dan Daud mengetahui bahwa Kami mengujinya; maka ia meminta ampun kepada Tuhannya lalu menyungkur sujud dan bertaubat". 33

Dalam suatu hadis yang diriwayatkan Abu Daud dari Abu Hurairah, Rasulullah SAWberkata:

"Allah swt. berfirman: 'Aku adalah pihak ketiga dari dua orangyang bersyarikat selama salah satu pihak tidak mengkhianatipihak yang lain. Jika salah satu pihak telah berkhianat, Akukeluar dari mereka." (HR. Abu Daud, yang dishahihkan oleh al-Hakim, dari Abu Hurairah).

Adapun dalam saham syariah terdapat beberapa penekanan yang membedakan dengan saham konvensional yaitu menurut kegiatan usahanya dan tujuan pembelian saham tersebut. Saham perusahaan yang kegiatannya usahanya bergerak di bidang yang halal dana tau dalam niat pembelian tersebut adalah investasi buka untuk spekulasi atau judi. Adapun saham yang sesuai syariah dapat dilihat pada listing di Jakarta Islamic Index. ${ }^{34}$

Mekanisme investasi Saham Syariah di Bursa Efek pada umumnya ditawarkan dalam dua bentuk yaitu penawaran melalui Pasar Perdana dan penawaran melalui Pasar Sekunder. Harga saham yang ditawarkan pada kedua pasar ini bisa berbeda dan secara mayoritas, harga saham di Pasar Sekunder jauh lebih tinggi dibandingkan harga saham di Pasar Perdana.Karena itu perdagangan
84.

\footnotetext{
${ }^{33}$ QS. Shad (38): 24.

${ }^{34}$ Abdul Aziz, Manajemen Investasi Syariah,
} 
saham di Pasar Sekunder lebih mendekati unsur spekulasi dengan risiko tinggi yang dilarang oleh Islam. Menurut Nasrun Harun, perdagangan saham di Pasar Sekunder sangat dipengaruhi oleh unsur insider trading, yaitu sampur tangan orang dalam terhadap penawaran saham di Bursa efek. Hal ini menyebabkan terjadinya kompetisi yang tidak sehat dikalangan investor. ${ }^{35}$

Sikap insider trading ini sama dengan bai' al-Khadhir lil-Baadi yaitu transaksi yang dilakukan oleh orang-orang kota ketika melakukan transaksi dengan orang-orang dusun dengan mendatangi mereka, yang didalamnya terdapat unsur penipuan, karena produsen (orang desa) tidak mengetahui secara pasti harga komoditas sebenarnya. Sementara sistem dan mekanisme perdagangan saham di pasar perdana masih merupakan perdagangan biasa, dimana selembar saham diperdagangkan sesuai dengan kuantitas yang masih wajar. Artinya saham yang ditawarkan dengan mengajukan harga tertentu yang ditetapkan berdasarkan keadaan perusahaan dan kekuatan pasar. ${ }^{36}$

Keuntungan yang diperoleh dari perdagangan saham ini masih dalam batas yang wajar dan dilakukan dengan prinsip transparansi, sehingga pemilik saham mengetahui segala persoalan yang berkaitan dengan perusahaan dan prospeknya di masa yang akan dating. Adapun mekanismen perdagangan saham syariah berbeda dengan perdagangan saham konvensional. Saham syariah secara spesifik dipertemukan pada Jakarta Islamic Indexs dan penawarannya hanya pada pasar perdana. Hal ini dilakukan agar tidak ada lagi unsur-unsur spekulasi dan sikap insider trading, sebagaimana yang terjadi pada pasar sekunder selama ini. Adapun mekanisme perdagangan saham syariah dapat dilihat pada gambar berikut:

\footnotetext{
${ }^{35}$ Abdul Aziz, Manajemen Investasi Syariah 85.

${ }^{36}$ Abdul Aziz, Manajemen Investasi Syariah

87.
}

Penawaran saham syariah diperdagangkan hanya pada Pasar Perdana, bukan pasar Sekunder. Hal ini dilakukan karena prinsipnya bahwa mekanisme perdagangan saham syariah pun harus sesuai dengan prinsip syariah, Karena di pasar sekunder unsur spekulasi, permainan netting, dan short selling secara riil dapat mengganggu kestabilan harga saham di Bursa efek, apalagi di kalangan peminat saham tindakan ini dikenal dengan nama "menggoreng saham" yang sudah pasti berdampak negative bagi stabilitas harga di bursa efek. Oleh karena itu penawaran umum di pasar perdana oleh investor dikembalikan pada Bursa efek akan tetapi Jakarta Islamic Index yang akan menampung dan mengeluarkan bentukbentuk saham syariahnya (stock screening) sebagai satu ketentuan bagi para investor yang akan menggunakan transaksi perdagangan saham syariah. ${ }^{37}$

\section{Sukuk (Obligasi Syariah)}

Obligasi berasal dari bahasa Belanda yaitu "Obligatie" yang dalam bahasa Indonesia disebut dengan "obligasi" yang berarti kontrak. Semenjak ada konvergensi pendapat bahwa bunga adalah riba, maka instrumen-instrumen yang mempunyai komponen bunga (interest-bearing instruments) keluar dari daftar investasi halal. Karena itu, dimunculkanlah alternatif yang dinamakan obligasi syariah. Menurut AAOIFI (Accounting and Auditing Organization for Islamic Finance Institution) Obligasi Syariah adalah sertifikat dengan nilai yang sama yang mewakili bagian kepemilikan yang sepenuhnya terhadap asset yang tangible, manfaat dan jasa, kepemilikan asset atas suatu proyek, atau kepemilikan dalam aktivitas investasi khusus.

Istilah obligasi dalam Islam lebih dikenal dengan istilah "sukuk" yang

${ }^{37}$ Satrio dan Saptono Budi, Optimasi Portofolio Saham Syariah: Studi Kasus BEJ Tahun 2002-2004 (Jakarta: PSKTTI-UI, 2005), 76. 
memiliki arti sama dengan sertifikat atau note. Mungkin penggunaan istilah "obligasi syariah" itu sendiri awalnya dianggap kontradiktif, sebab kata obligasi sudah menjadi kata yang tak lepas dari bunga sehingga agak susah untuk di-syariah-kan. Perlu digaris bawahi disini, yang dimaksud obligasi syariah adalah "surat berharga jangka panjang" bukan "surat hutang jangka panjang”. Obligasi syariah dapat diterbitkan dengan menggunakan prinsip mudharabah, musyarakah, ijarah, istisna', salam dan murabahah. Tetapi diantara prinsip-prinsip instrumen obligasi tersebut yang paling banyak dipergunakan di Indonesia adalah obligasi dengan insturmen prinsip mudharabah dan ijarah.

\section{PEMBAHASAN DAN DISKUSI}

\section{Analisis Investasi perspektif Maqashid Syariah}

Kegiatan Investasi dalam segala bentuknya merupakan salah satu pendorong bagi kemajuan ekonomi masyarakat, Sebab tidak selamanya seseorang dalam mengembangkan usahanya akan selalu berada pada kondisi mapan secara finansial. Sehingga membutuhkan phak-pihak yang memiliki kelebihan finansial untuk diikutsertakan modal finansialnya dalam kegiatan usaha bersama dengan pola simbiosis mutualisme. Telah diterangkan pada awal tulisan ini bahwa investasi sesuai dengan sektor usahanya terbagi menjadi investasi berbasis real asset dan investasi berbasis financial asset. Investasi berbasis real asset sudah banyak dicontohkan dalam hadits nabi yang artinya sebagai berikut:

Dari al-Sa'ib al-Mahzumi (r.a) bahwa beliau pernah menjadirakan kongsi Rasulullah (s.a.w) sebelum diutus menjadi rasul. Dia datangpada hari pembukaan kota Makkah lalu baginda bersabda: "Selamat datangdengan saudaraku dan rakan kongsiku." (Diriwayatkan oleh Imam Ahmad, Abu Dawud dan Ibn Majah: 904).
Daripada Jabir bin Abdullah (r.a), beliau berkata: "Saya ingin keluar menuju Khaibar, kemudian aku mendatangi Rasulullah (s.a.w) dan baginda bersabda: "Jika kamu mendatangi wakilku di Khaibar, ambillah lima belas wasaq daripadanya." (Diriwayatkan oleh Abu Dawud sekali gus menilainya sahiah: 906).

Investasi berbasis financial asset dalam sejarah Islam belum ada praktik yang dicontohkan baik oleh Nabi sendiri maupun oleh para Ulama. Era modern saat ini investasi merupakan kegiatan yang umum dilakukan banyak orang dan bahkan telah difasilitasi oleh lembaga (bursa efek) dan diatur dalam undang-undang. Seperti yang telah penulis jelaskan dalam contoh saham syariah, sukuk, dan obligasi syariah, bahwa praktik ketiganya bila didasarkan pada beberapa dalil syar'i telah memenuhi kriteria kesyariahan karena meskipun basis kegiatannya adalah financial asset namun masih berhubungan dengan real asset dalam bentuk usaha halal yang dijalankan perusahaan-perusahaan yang menyertakan dirinya dalam bursa efek melalui proses screening. Namun yang menjadi problem adalah ketika para emiten yang telah melakukan penawaran pada investor di pasar perdana, mereka kemudian diberikan kewenangan untuk melakukan penwaran di pasar sekunder melalui para broker (pialang saham) dengan alasan model penawaran saham di pasar sekunder memiliki fleksibilitas dan mampu menjaring lebih banyak investor tambahan baik perorangan maupun secara kolektif. Dalam hal ini pola yang digunakan sering kita dengar dengan sebutan option, spot, dan warrant. Pola ini menjelaskan bahwa dalam penawaran saham ada batas atas dan batas bawah dari harga saham.Kemudian terdapat pula batas waktu penjualan saham tersebut. Jika spot jangka waktunya 2 x 24 jam, sesuai dengan batas penentuan harga saham di bursa efek. Sedangkan option dan warrant batas waktu penjualanya bisa lebih dari 2 x 24 jam. 
Pola yang pertama (spot) merupakan pola penawaran saham di pasar sekunder yang telah ditetapkan harganya secara ketat dan berbatas waktu oleh bursa efek. Memang pada umunya bursa efek menetukan harga saham di pasar sejunder dalam kurun wakru tersebut. Bila lebih dari 2 x 24 jam maka penjualan tidak boleh dilakuan atau dengan kata lain harga yang berlaku pada penawaran sebelumnya tidak berlaku lagi pada penawaran baru setelah jangka waktu 2 x 24 jam. Sehingga para broker dan investor tidak bisa melakukan gambling (maysir) harga saham secara leluasa. Maka penggunaan pola ini menurut hemat penulis masih diperbolehkan dalam konteks syariah karena tidak adanya gambling (maysir) akan menutup pintu riba dan gharar.

Pola kedua (option dan warrant) sangat berpotensi pada aktivitas gambling yang membuka pintu riba dan gharar, sebab penetuan harga pada penawaran pertama bisa diberlakukan (dijual belikan) pada penawaran kedua dan seterusnya. Hal ini memungkinkan terjadinya spread (selisih harga yang berlaku pada penawaran pertama dan penawaran kedua) yang sangat sarat denga riba dan gharar. Jelas ini tidak diperbolehkan dalam Islam. Terdapat dampak yang buruk baik secara mikro maupun makro ekonomi. Secara mikro seorang investor telah melakukan transaksi yang tidak jelas, tidak halal, dan tidak seimbang antara usaha dengan hasilnya. Dampaknya pada mental pelaku yang terbiasa dengan usaha yang kecil, menginginkan hasil yang besar. Secara makro kegiatan ini akan menimbulkan pasar derivatif yang bepotensi terjadinya bubble economic yang berdampak pada jatuhnya nilai mata uang hanya berdasarkan pada kecenderunga "pasar" bukan pada meningkatnya atau menurunnya produktivitas riil yang pada akhirnya dapat menjatuhkan ekonomi suatu bangsa pada lubang krisis moneter.
Bila kembali pada kaidah syariat dapat dilihat pada beberapa ayat Al-Qur'an, Al-Hadits, sebagai berikut ini:

1. Al-Qur'an Surat Al-Baqarah 278-279:

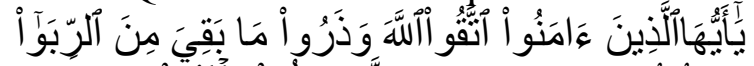

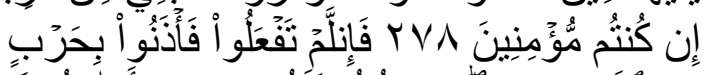

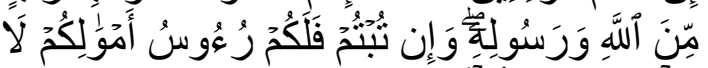

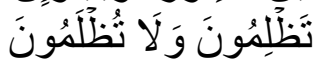

Artinya: "Hai orang-orang yang beriman, bertakwalah kepada Allah dan tinggalkan sisa riba (yang belum dipungut) jika kamu orang-orang yang beriman. Maka jika kamu tidak mengerjakan (meninggalkan sisa riba), maka ketahuilah, bahwa Allah dan Rasul-Nya akan memerangimu. Dan jika kamu bertaubat (dari pengambilan riba), maka bagimu pokok hartamu; kamu tidak menganiaya dan tidak (pula) dianiaya". 38

Al-Qur'an Surat An-Nisa' Ayat 29:

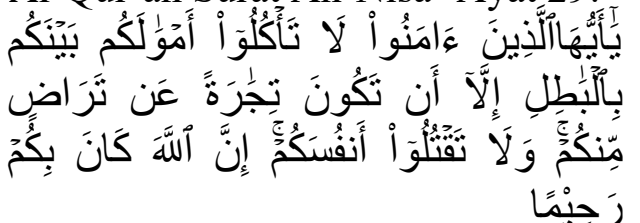

Artinya: "Hai orang-orang yang beriman, janganlah kamu saling memakan harta sesamamu dengan jalan yang batil, kecuali dengan jalan perniagaan yang berlaku dengan suka sama-suka di antara kamu. Dan janganlah kamu membunuh dirimu; sesungguhnya Allah adalah Maha Penyayang kepadamu". ${ }^{39}$

2. Al-Hadits

Dari Abu Sa'id al-Khudri ra. bahwa Rasulullah Saw. bersabda: "Jangan kamu menjual emas dengan emas kecuali dengan timbangan yangsama dan jangan kamu melebihkan satu timbangan dengan yang lain, jangankamu menjual perak dengan perak kecuali dengan timbangan yang samadan jangan kamu melebihkan satu

\footnotetext{
${ }^{38}$ QS. Al-Baqarah (2): 278-279.

${ }^{39}$ QS. An-Nisa' (4): 29.
} 
timbangan dengan yang lain, dan jangankamu menjual keduanya di mana salah satu daripadanya dijual tunah dansatunya lagi dijual secara angsur" (Muttafaq alahi: 853).

Dari Jabir bin Abdullah (r.a),
beliau (s.a.w)melarang daripada menjual setimbun makanan (kurma) yang belumdiketahui takarannya sesuai dengan takaran yang telah disepakati." (Diriwayatkan oleh Muslim: 857).

Berdasarkan beberapa keterangan dari al-Qur'an dan Hadits di atas dapat disimpulkan bahwa investasi keuangan yang masuk dalam kategori pasar perdana diperbolehkan secara syariat Islam. Demikian pula investasi pada pasar sekunder kategori spot juga diperbolehkan. Namun investasi keuangan pada pasar sekunder dengan kategori option dan warrant bila melihat aspek kebaikannya tidak diperbolehkan dalam Islam meskipun menjanjikan keuntungan tambahan yang lebih cepat bagi para pelaku investasi. Namun dampaknya secara makro dalam jangka panjang akan buruk dan bisa jadi menyebabkan krisis ekonomi oleh karena aktivitas penggandaan uang secara fiktif melalui incestasi tersebut.

\section{KESIMPULAN}

Berdasarkan hasil penelitian dapat disimpulkan bahwa pada prinsipnya investasi khsuusnya di sector keuangan dibolehkan dalam Islam bagaimana pun bentuk skema investasinya asalkan memenuhi ketentuan Syariat Islam dan tidak mengandung riba, maysir, dan gharar. Terkadang dengan maraknya investasi yang menjanjikankeuntungan besar dengan usaha yang ringan dianggap sebagai investasi yang lumrah dan boleh dilakukan karena sudah umum berlaku di masyarakat.

Ditinjau dari sisi kebaikannya secara finansial sangat mengganggu stabilitas keuangan baik bagi pelaku investor maupun secara makro bagi kondisi stabilitas nilai mata uang (volatilitas). Meskipun usaha investasi itu awalnya berbasis riil dan halal tetapi bila kemudian dijual berdasarkan metode penjualan di pasar derivative akan menjadi sarat riba, maysir, dan gharar yang dalam beberapa dalil syariat dilarang karena tidak menjadikan kebaikan dalam berinvestasi sesuai yag diajarkan oleh Islam.

\section{DAFTAR PUSTAKA}

Anisyah, Nindiah Noer. Peran Negara dalam Penyelenggaraan Ibadah Haji. Malang: FISIP Universitas Brawijaya, 2013.

Aziz, Abdul. Manajemen Investasi Syariah. Bandung: Penerbit Alfabeta, 2010.

Chapra, Umer. Sistem Moneter Islam. Jakarta: Gema Insani Press, 2000.

Faizal Noor, Henry. Investasi, Pengelolaan Keuangan Bisnis dan Pengembangan Ekonomi Masyarakat. Jakarta: PT. Indeks, 2009.

Fakhruddin, Hendy M. dan Tjiptono Darmadji. Pasar Modal di Indonesia. Jakarta: Salemba Empat, 2001.

Fatwa Dewan Syariah Nasional tentang obligasi Syariah Nomor 33/DSNMUI/ IX/2002.

Firdaus, Muhammad, et. al. Konsep Dasar Obligasi Syariah. Yogyakarta: Renaisan, 2005.

Halim, Abdul. Analisis Investasi. Jakarta: Salemba Empat, 2003.

Hamid, Abdul. Pasar Modal Syariah. Jakarta: Lembaga Penelitian UIN Jakarta, 2009.

Haron, Mohamad Sabri. "Wealth Protection in The Context of Maqasid Syariah: Malaysia's Role ini Realizing The Concept of Economic Jihad", Jurnal Hadhari Edisi Khas, Vol. 2, No. 2 (Desember 2017).

Huda, Nurul dan Mustafa Edwin Nasution. Investasi pada Pasar Modal Syari'ah. Jakarta: Kencana, 2007.

Iggi H., Achsien. Investasi Syariah di Pasar Modal: Menggagas Konsep dan Praktek Manajemen Portofolio 
Syariah. Jakarta: Gramedia Pustaka Utama, 2003.

Khisan, Zariatul. "Analisis kinerja perbankan syariah ditinjau dari profitabilitas dan maqasid syariah tahun 2010-2013)". Tesis. Malang: Universitas Islam Negeri Malik Ibrahim, 2015.

Manan, Abdul. Aspek Hukum dalam Penyelengaraan Investasi di Pasar Modal Syariah Indonesia. Jakarta: Kencana Prenada Media Group, 2009.

Mulyadi. Sistem Akuntansi Manajemen, Edisi Ketiga. Jakarta: Salemba Empat, 2011.

Nazir, Moh. Metode Penelitian. Bandung: Ghalia Indonesia, 2003.

Rahmat, Jalaludin. Metodologi Hukum. Jakarta: Fajar Agung, 1997.

Riyanto, Bambang. 1995, Dasar-dasar Pembelanjaan, Yogyakarta; BPFE, 1995.

Satrio, Saptono Budi. Optimasi Portofolio Saham Syariah: Studi Kasus BEJ tahun 2002-2004. Jakarta: PSKTTIUI, 2005.

Soekanto, Soerjono dan Sri Mamudji. Penelitian Hukum Normatif Suatu Tinjauan Singkat, Cet. 11. Jakarta: PT. Raja Grafindo Persada, 2009.

Soemitra, Andri. Bank dan Lembaga Keuangan Syariah. Jakarta: Kencana Prenada Media Group, 2009.

Sudarsono, Heri. Bank dan Lembaga Keuangan Syariah Deskripsi dan Ilustrasi. Yogyakarta: Ekonisia, 2004.

Sugiyono. Metode Penelitian Kuantitatif Kualitatif Dan $R$ \& D. Bandung: Alfabeta, 2013.

Sula, M. Syakir. Asuransi Syaraiah: Konsep dan Sistem Operasional. Jakarta: Gema Insani Press, 2004.

Supriyono, 1987, Akuntansi Biaya, BPFE; Yogyakarta, 1987.

Sutedi, Andrian. Pasar Modal Syariah. Yogyakarta: Sinar Grafika, 2005.
Yuliana, Indah. Investasi Produk Keuangan Syariah. Malang: UIN Maliki Press, 2010. 